\title{
KRONIK OTITIS MEDIALI HASTALARDA SAPTANAN NAZAL PATOLOJILER
}

\author{
Nasal Pathologies Encountered in Patients With Chronic \\ Otitis Media
}

\author{
Kamran Sarı ${ }^{1}$, Müge Özcan ${ }^{2}$, Yavuz Fuat Yılmaz ${ }^{2}$, Adnan Ünal ${ }^{2}$
}

${ }^{1}$ Bozok Üniversitesi, Tıp Fakültesi, Kulak Burun Boğaz Hastalıkları Anabilim Dalı,

Yozgat

${ }^{2}$ Ankara Numune Eğitim ve Araştırma Hastanesi KBB Kliniği, Ankara
Kamran Sarı, Yrd. Doç. Dr. Müge Özcan, Doç. Dr. Yavuz Fuat Yılmaz, Doç. Dr. Adnan Ünal, Prof. Dr.

İetişim:

Yrd. Doç. Dr. Kamran Sarı Bozok Üniversitesi Tip FakültesiKulak Burun Boğaz Hastalıkları Anabilim Dalı, Yozgat Tel: 03542127060 e-mail: kamransari@gmail.com

Geliş tarihi/Received:01.04.2014 Kabul tarihi/Accepted:13.05.2014

\section{ÖZET}

Amaç: Bu çalışmada kronik otitis medialı (KOM) hastalarda nazal patolojiler araştırıldı. Gereç ve Yöntemler: Ocak 2007 ile Temmuz 2007 tarihleri arasında KOM tanısı olan 150 hasta (87 kadın, 63 erkek; ort. yaş 35.6; dağılım 7-78) ile kontrol grubu olan 100 hasta (57 kadın, 43 erkek; ort. yaş 43.9; dağılım 7-85) incelendi. KOM'lu hastalarda ve kontrol grubunda nazal patolojiler incelendi. Verilerin analizi SPSS 11,5 paket programında yapıldı.

Bulgular: İncelenen 150 KOM'lu hastanın 73'ünde septum deviasyonu (\%48.7) saptandı. 100 hastadan oluşan kontrol grubunda 28 (\%28) hastada septum deviasyonu saptandı. Ayrıca KOM'lu hastalarda ve kontrol grubunda alt konka hipertrofisi, paradoks orta konka ve Waters filmleri karşılaştırıldı ama istatiksel olarak anlamlı bir fark saptanmadı.

Sonuç: Yaptığımız bu çalışmada, KOM'lu hastalarda kontrol grubuna göre istatiksel olarak anlamlı oranlarda septum deviasyonu saptanması, bize KOM etyopatogenezinde bu patolojilerin rol oynayabileceğini düşündürmektedir. Bu nedenle fizik muayene ile çok kolay tespit edilebilen bu patolojinin tedavisinde gecikilmemesi ve KOM'lu hastalarda eşlik eden septum deviasyonunun kulak operasyonundan önce tedavi edilmesi gerektiğini düşünmekteyiz.

Anahtar kelimeler: Kronik otitis media; Septum deviasyonu; Nazal patoloji.

\section{ABSTRACT}

Objective: Nasal pathologies encountered in patients with chronic otitis media were examined in the current study.

Material and Methods: One hundred and fifty patients (87 females, 63 males; mean age 35.6 years; range 7-78 years) diagnosed with chronic otitis media between January 2007 and July 2007 and one hundred healthy controls ( 57 females, 43 males; mean age 43.9 years; range 7-85 years) were examined. The nasal pathologies in the two groups were examined. The data were analyzed using SPSS package program.

Results: Nasal septal deviation was encountered in seventy-three $(48.7 \%)$ patients with chronic otitis media, and in twenty-eight (28\%) patients in the control group. The presence of inferior turbinate hypertrophy and paradoxical middle turbinate, and findings in Waters view radiographs of the patients with chronic otitis media and control subjects were also evaluated. There was no significant difference between the two groups in terms of the frequency of nasal pathologies.

Conclusion: In our study, the significantly higher prevalence of septal deviation observed in patients with chronic otitis media compared to control group, suggests that nasal pathologies might play a role in the etiopathogenesis of chronic otitis media. We therefore postulate that treatment of such pathologies should not to be delayed considering that the condition is easy to diagnose on physical examination and accompanying septal deviation in patients with chronic otitis media should be treated before performing an ear surgery.

Key words: Chronic otitis media; Septal deviation; Nasal pathology 


\section{INTRODUCTION}

Chronic otitis media (COM) has been known since prehistoric times (1). It has three main characteristics including a perforated tympanic membrane, intermittent suppurative ear discharge and hearing loss (1). Most inflammatory diseases of the middle ear are thought to be associated with inadequate ventilation of the middle ear caused by Eustachian tube dysfunction (2). Pathologic conditions of the nose, paranasal sinuses and rhinopharyx cause Eustachian dysfunction, and nasal obstruction is one of the factors impairing Eustachian function $(3,4,5,6)$.

In this study, we examined patients with chronic otitis media for the presence of nasal pathologies and we investigated the relationship between nasal pathologies and chronic otitis media.

\section{MATERIAL AND METHOD}

A hundred and fifty patients with COM, who presented with ear discharge and hearing loss between January 2007 and July 2007, were included in this study. All patients underwent otologic, anterior rhinoscopic and endoscopicnasal examination. Waters' view radiographs of paranasal sinuses were obtained. Perforation of the tympanic membrane, middle ear mucosa and to a certain extent ossicles were examined in otologic examinations, and the nasal septum, turbinates and nasopharynx were examined in the anterior rhinoscopic and endoscopic nasal examinations. A hundred patients, who were admitted to any of the outpatient clinics other than ENT outpatient clinic with no middle ear pathology, were taken as the control group. The data were analyzed using SPSS 11.5 package program. Descriptive statistics were expressed as percentages for categorical variables. The Chi-Square and Fischer's Exact tests were used for categorical comparisons. A p value of $<0,05$ was considered statistically significant.

\section{RESULTS}

Two hundred and fifty patients, 150 patients with COM and 100 control subjects were included in this study. The sex distribution and mean age in the groups are presented in (Table 1).
Table 1. The distrubition of gender and age in patient and control group

\begin{tabular}{llll}
\hline & \multicolumn{3}{l}{ Gender } \\
& Men & \multicolumn{2}{l}{ Women age } \\
\hline Patient Group & 63 & 87 & 35,6 \\
Control Group & 43 & 57 & 43,9 \\
Total & 106 & 144 & 39,8 \\
\hline
\end{tabular}

Of 150 patients in the study group, 90 (60\%) had unilateral and 60 (40\%) had bilateral COM. On anterior rhinoscopic and nasal endoscopic examinations, septal deviation was found in $48.6 \%(n=73)$ of patients with COM and in $28 \%$ of the patients in the control group $(n=28)$ (Table 2).

Table 2. The comparison of septal deviation ratio.

\begin{tabular}{|c|c|c|c|c|c|c|}
\hline & \multicolumn{3}{|c|}{ Septal Deviation } & \multirow[b]{2}{*}{ Ratio } & \multirow[b]{2}{*}{ Total } & \multirow[b]{2}{*}{ Ratio } \\
\hline & Right & Ratio & Left & & & \\
\hline $\begin{array}{l}\text { Patient } \\
\text { group }\end{array}$ & 37 & $\% 24,6$ & 36 & $\% 24$ & 73 & $\% 48,6$ \\
\hline $\begin{array}{l}\text { Control } \\
\text { group }\end{array}$ & & $\% 17$ & 11 & $\% 11$ & 28 & $\% 28$ \\
\hline
\end{tabular}

Septal deviation was significantly more prevalent in the study group compared to the control group $(p=$ 0.004). Of the patients, 90 had unilateral and 60 had bilateral COM. Of the patients with COM, 53.6\% ( $n=22)$ had ipsilateral septal deviation and $46.3 \%(n=19)$ had contralateral septal deviation.

On anterior rhinoscopic and nasal endoscopic examinations, the prevalence of turbinate hypertrophy was found to be $34 \%$ in the study group $(n=51)$ and $25 \%$ $(n=25)$ in the control group. Although the prevalence of turbinate hypertrophy was higher in the study group, the difference was not statistically significant $(p=$ 0,105). 
Paradoxical middle turbinate was determined in $10 \%$ $(n=15)$ of the patients in the study group and $5 \%(n=5)$ of the patients in the control group. Although paradoxical turbinate was numerically higher in the study group, the difference between the groups was not significant $(p=0,075)$. The findings in Waters' view radiographs of the study and control groups are shown in (Table 3 ).
When the two groups were compared, no significant difference was observed between the groups $(p=0,046)$ other than mucosal thickening in maxillary sinuses. Mucosal thickening in maxillary sinuses was significantly more prevalent in the study group compared to control group $(p=0,005)$

Table 3. The Waters graphy results and ratio in patient and control group.

\begin{tabular}{lllcc}
\hline Finding & Patient group & Ratio & Control group & Ratio \\
& $\mathrm{n}$ & $\mathrm{n}$ & & \\
\hline Thickness in maxillary sinus & 30 & $\% 20$ & 7 & $\% 7$ \\
Loss of aeration in maxillary sinus & 19 & $\% 12,5$ & 12 & $\% 12$ \\
Hypoplasia in frontal sinus 6 & $\% 4$, & 1 & 9 & $\% 9$ \\
Loss of aeration in frontal sinus & 3 & $\% 1,6$ & 4 & $\% 4$ \\
\hline
\end{tabular}

\section{DISCUSSION}

Chronic otitis media is an inflammatory disease of the middle ear, Eustachian tube and mastoid cell system, lasting for more than three months and unresponsive to medical therapies (1).

In a study by Kim et al. on 2899 households, the prevalence of COM was found to be $2.19 \%$ (7). Most inflammatory diseases of the middle ear are thought to be associated with inadequate ventilation of the middle ear through the Eustachian tube. Pathologic conditions of nose, paranasal sinuses and rhinopharynx cause Eustachian dysfunction, and nasal obstruction impairs the functions of the Eustachian tube $(3,4,5,6,8)$. When Eustachian tube is obstructed, the negative pressure in the middle ear leads to an increase in the capillary blood flow. Tympanic membrane retraction, transudation into the middle ear or in advanced forms, perforation can occur due to this vacuum effect (9).

Van Cauwenberge et al. conducted a prospective study on $\mathbf{2 0 5 9}$ healthy children and found a higher prevalence of Eustachian tube dysfunction among children with even minimal deviation compared to those witho- ut septal deviation (10). Post-operative early and late measurements in some studies suggest that surgical correction of septal deviation improves tubal opening pressure at both sides $(11,12,13,14)$. Septum supports nasal structures and has an important role in nasal physiology (14). The most common reason for nasal obstruction is nasal septal deviation $(15,16)$. The incidence of septal deviation was found to be $40 \%$ in a study that used sinus computed tomography (17). Göçmen et al. examined nose and paranasal sinus pathologies in 52 patients diagnosed with adhesive otitis, pars tensa atelectasis or pars flaccida retraction pockets; the prevalences of septal deviation and concha bullosa were $52 \%$ and $29 \%$ in the study group, and $17 \%$ and $23 \%$ in the control group, respectively (18). In our study, the prevalence of septal deviation was higher in the study group compared to control group, and the difference was statistically significant $(p=0.004)$. In patients with COM, there was no relationship between the affected side and the localization side of septal deviation $(P=0,192)$. This finding suggests that the effects of septal deviation on Eustachian tube dysfunction are bilateral and not unilateral. 
Furthermore, we investigated the presence of inferior turbinate hypertrophy and paradoxical middle turbinate in both groups and, observed no significant difference between the groups. We also compared the findings on Waters' view radiographs of the study and control group, and no significant difference was found between the groups other than mucosal thickening in maxillary sinuses.

\section{CONCLUSION}

In this study, we could not find significant increases in the prevalence of turbinate hypertrophy and paradoxical middle turbinate in patients with COM compared to the control group. This finding suggests that there is no relationship between these pathologies and COM. However, the significantly higher prevalence of septal deviation found in patients with COM compared to the control group suggests that these pathologies might play a role in the etiopathogenesis of COM. We, therefore, postulate that treatment of such pathologies should not be delayed considering that the condition is easy to diagnose on physical examination and accompanying septal deviation in patients with COM should be treated before performing an ear surgery.

\section{KAYNAKLAR}

1. Akyıldız N. Kulak hastalıkları ve mikrocerrahisi. In Akyıldız $\mathrm{N}$, eds. Kulak Hastalıkları ve mikrocerrahisi. Vol. 1. Ankara: Bilimsel Tıp Yayınevi, 1998. p. 22-90.

2. Salvinelli F, Casale M, Greco F. Nasal surgery and Eustachian tube function: Effects on middle ear ventilation. Clin. Otolaryngol. Allied. 2005;30(5):409-13.

3. Farneti G, Denaro E. Rhino-pharingeal disease and tubal disease . Relations and influences. In Pirodda E, eds. Middle Ear Disease and Surgery Compositori. Vol. 2. Bologna: Lippincott Williams Wilkins, 1992. p. 199-204.

4. Gonzalez Garcia F, Garabal Garcia - Talavera J. A. The Toynbee's phenomenon effect on the middle ear during nasal tamponade. An. Otorhinolaryngology. ibero Am. 1997;24(4):393- 400.

5. Lee CS, Paparella MM. Otitis media. In Goodhill V, eds: Ear diseases Deafness and Dizziness. Vol. 2. Philadelphia: Hagerstown, 1979. p. 526-46.
6. Hone S W, Moodley S, Donnelly M J. The effect of tonsillectomy on the Eustachian tube function. Clin. Otolaryngol. 1997;22(6):511-14.

7. Kim CS, Jubg HW, Yoo KY. Prevalance and risk factors of chronic otitis media in Korea: results of a nation-wide survey. Acta Otolaryngol. 1993;113(3):369-75.

8. Yücetürk A. V, Ünlü H.H, Filiz Ü, Yıldız T, Okumuş M. Kronik otitli hastalarda Östaki Tüpü fonksiyonlarının objektif metotla değerlendirilmesi ve normal kişilerle karşılaştırılması. K.B.B ve Baş Boyun Cerrahisi Dergisi.1996;4(2):144-8.

9. Thorburn I B. The pathogenesis of chronic otitis media - A clinical study. Proc. Roy. Soc. Med. 1968;61(4):395-99.

10. Van Cauwenberge P. Derycke A. The relationship between nasal and middle ear pathology. Acta Otorhinolaryngol. Belg. 1983;37(6):830-41.

11. Deron P. Septal surgery and tubal function, early and late results. Rhinology. 1995;33(1):7-9.

12. Lim D J. Surfice active substance of the tubatympanum. A review. In O Passali eds. Nose and Eustachian tube. Vol. 1. Roma: CIC Ed, 1989. p. 109-23.

13. Tos M. Pathology of the Eustachian tube. Ann. Otol. Rhinol. Laryngol. 1985;43 (120):17-8.

14. Grote J. Middle ear effusion and sinusitis. J. Laryngology Otol. 1980;94(2):177-83.

15. Uygur K, Tuz M, Dogru H. The correlation between septal deviation and concha bullosa. Otolaryngol. Head Neck Surgery. 2003;129(1):33-6.

16. Akçalı Ç. Nazal septum hastalıkları. In Onur Çelik eds. Kulak Burun Boğaz Hastalıkları ve Baş Boyun Cerrahisi. 2. Baskı. İstanbul: Turgut yayıncılık, 2002. p. 435.

17. Arslan H, Aydinlioglu A, Bozkurt M. Anatomic variations of the paranasal sinuses: CT examination for endoscopic sinus surgery. Auris Nasus Larynx. 1999;26(1):39-48.

18. Gocmen H, Ceylan K, Arslan I, Kılıc R, Ozeri C, Samim $\mathrm{E}$, Arslan N. Burun ve paranazal sinüs patolojilerinin timpanik membran retraksiyonları üzerinde etkisi var mıdır? Otoscope. 2004;(1):34-8. 